\title{
Design and Synthesis of a Lactam-Steroid Derivative and their Theoretical Interaction with a SAR-COV2
}

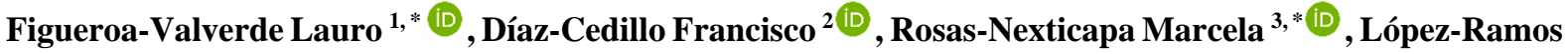 \\ Maria 1(D), Mateu-Armad Maria Virginia 3(D), Garcimarrero E. Alejandara 4iD, Raquel \\ Estrella-Barron 5 (D), Cauich-Carrillo Regina ${ }^{1}$ (i) \\ 1 Laboratory of Pharmaco-Chemistry, Faculty of Chemical Biological Sciences, University Autonomous of Campeche, Av. \\ Agustín Melgar s/n, Col Buenavista C.P. 24039 Campeche, Camp., México \\ 2 Escuela Nacional de Ciencias Biológicas del Instituto Politécnico Nacional. Prol. Carpio y Plan de Ayala s/n Col. Santo \\ Tomas, México, D.F. C.P. 11340 \\ 3 Facultad de Nutrición, Universidad Veracruzana, Médicos y Odontologos s/n C.P. 91010, Unidad del Bosque Xalapa \\ Veracruz, México \\ 4 Facultad de Medicina, Universidad Veracruzana, Médicos y Odontologos s/n C.P. 91010, Unidad del Bosque Xalapa \\ Veracruz, México \\ 5 Universidad Autonoma del Carmen, Fac. de Ciencias de la Salud, Campus III. Av. Central s/n, Fracc. Mundo Maya, C.P. \\ 24153, Cd. del Carmen Campeche Mexico \\ * Correspondence: 1figuero@uacam.mx (F.V.L); rosasnm@yahoo.com.mx (R.N.M);
}

Received: 10.06.2020; Revised: 27.06.2020; Accepted: 29.06.2020; Published: 3.07.2020

\begin{abstract}
Several drugs have been developed for the treatment of severe acute respiratory syndrome coronavirus (SARS-CoV) using different protocols; however, some methods use different reagents that are dangerous and require special conditions. The objective of this research was to synthesize a Lactamsteroid derivative to evaluate its theoretical interaction with SARS-CoV using at 6LU7-protein as a theoretical model. Furthermore, this interaction was carried out in a docking model using hydroxychloroquine and favipiravir as controls. The results showed that the binding energy involved in the interaction of the lactam-steroid derivative with 6LU7 protein surface was lower compared with both hydroxychloroquine and favipiravir. In conclusion, the lactam-steroid derivative could be an alternative therapeutic to treatment of SARS-CoV.
\end{abstract}

Keywords: Lactam; steroid; coronavirus; hydroxychloroquine; favipiravir.

(C) 2020 by the authors. This article is an open-access article distributed under the terms and conditions of the Creative Commons Attribution (CC BY) license (https://creativecommons.org/licenses/by/4.0/).

\section{Introduction}

Infectious diseases are a serious health problem worldwide; some of these clinical pathologies can be produced by several virus strains [1-3]. It is noteworthy that there are drugs used as antivirals; however, some of these drugs have low activity against different virus strains [4-7] In search of new therapeutic alternatives for the treatment of virus strain, some compounds have been developed; for example, the preparation of a 1,2,3-triazole analog from 2,2-Dimethyl-6-trityloxymethyl-4,6a-dihydro-3aH-cyclopenta-[1,3]dioxol-4-ol as an antiviral agent against vaccinia virus [8]. Besides, a study showed the synthesis of N.N-(3,4Dichlorobenzyl)-2-(3,5-diphenyl-1H-pyrazol-1-yl)-4-methylthiazole-5-carboxa-mide via reaction of (11).3,4-dichloro-benzylamine with 2-(3,5-diphenyl-1H-pyrazol-1-yl)-4-methylthiazole-5-carboxylic acid with antiviral activity against a flavivirus strain [9]. Other report has 
shown the synthesis of 6-[2-(phosphonomethoxy)alkoxy]pyrimidines from diisopropyl 2(chloroethoxy)methyl-phosphonate with antiviral activity on herpes viruses [10].

On the other hand, a series of steroid derivatives have been prepared as antiviral agents; in this way the compound $2 \beta, 3 \alpha$-dihydroxy-5 $\alpha$-cholestane disulfate from Triethylamine-sulfur

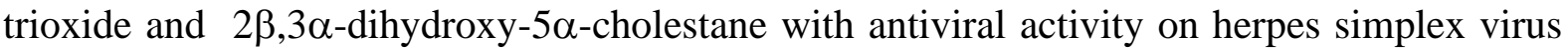
type 2 (HSV-2) [11]. Furthermore, a study showed thr synthesis of (22S,23S)-3 $\beta$-bromo$5 \alpha, 22,23$-trihydroxystig-mastan-6-one from stigmasterol as vesicular stomatitis virus inhibitor [12]. Other data have shown the synthesis of (20R,22R)-3â-Butyryloxycholestane-16â,20,22orthobutyrate from a $20 \mathrm{~S}, 22 \mathrm{Repoxide}$ derivative, TFA, and $\mathrm{CDCl}_{3}$ as antiviral against mouse coronavirus [13]. In addition, a study showed the synthesis of Disodium 2b,3a,21-trihydroxy(20R)-cholesta-5,24-diene 3-acetate, 2,21-disulfate via acetylation of a disulfate polyhydroxysteroid analog with pyridine to evaluate their antiviral activity against HSV-2 [14]. All these data indicate that several steroid derivatives can exert antiviral activity on some virus strain; however, the interaction with the virus surface is confusing, perhaps this phenomenon could be due to their different chemical structures. Analyzing all these data the objective of this investigation was to prepare two new steroid derivatives from both estradiol and estrone to evaluate their interaction with the SARS-CoV-2 surface using a docking model.

\section{Materials and Methods}

The compound 13-Methyl-2-nitro-17-oxo-7,8,9,11,12,13,14,15, 16,17-decahydro-6Hcyclopenta[a]phenanthrene-3-carbaldehyde (1) was prepared using a previously method reported [15]. Besides, other compounds used in this investigation were acquired from SigmaAldrich Co., Ltd. The melting point for compounds was evaluated on an Electrothermal (900 model). Infrared spectra (IR) were evaluated with a Thermo Scientific iSOFT-IR spectrometer. ${ }^{1} \mathrm{H}$ and ${ }^{13} \mathrm{C}$ NMR spectra were determined using a Varian VXR300/5 FT NMR spectrometer at $300 \mathrm{MHz}$ in $\mathrm{CDCl}_{3}$ using TMS as internal standard. EIMS spectra were obtained with a Finnigan Trace Gas Chromatography Polaris Q-Spectrometer. Elementary analysis data were acquired from a Perkin Elmer Ser. II CHNS/02400 elemental analyzer.

Synthesis of 3-hydroxy-3-[(13S)-13-methyl-2-nitro-17-oxo-7,8, 9,11,12,14,15,16-octahydro-6H-cyclopenta[a]phenanthren-3-yl]propanenitrile (2).

In a round bottom flask $(10 \mathrm{ml})$, compound 1 (200 mg, $0.60 \mathrm{mmol}), n$-Butyllitium (200 $\mu 1.2 .12 \mathrm{mmol})$ and actonitrile $(5 \mathrm{ml})$ were stirred at room temperature for $72 \mathrm{~h}$. Then, the solvent was evaporated under reduced pressure and following the product was purified via crystallization using the methanol:hexane:water (4:1:1) system; yielding 65\% of product; m.p. 138-140 ${ }^{\circ} \mathrm{C}$; IR $\left(V_{\max }, \mathrm{cm}^{-1}\right) 3334,1712$ and 1540: ${ }^{1} \mathrm{H}$ NMR $\left(300 \mathrm{MHz}, \mathrm{CDCl}_{3}-d\right) \delta_{\mathrm{H}}: 0.92$ (s, $3 \mathrm{H}), 1.20-1.52(\mathrm{~m}, 5 \mathrm{H}), 1.68$ (broad, 1H), 1.80-2.80 (m, 9H), $3.02(\mathrm{~m}, 1 \mathrm{H}), 3.04(\mathrm{~m}, 1 \mathrm{H}), 3.20$ $(\mathrm{m}, 1 \mathrm{H}), 4.86(\mathrm{~m}, 1 \mathrm{H}), 7.30-8.04(\mathrm{~m}, 2 \mathrm{H}) \mathrm{ppm} .{ }^{13} \mathrm{C} \mathrm{NMR}\left(300 \mathrm{~Hz}, \mathrm{CDCl}_{3}\right) \delta_{\mathrm{C}}: 13.82,21.70$, $25.42,27.49,27.52,29.30,31.02,35.02,37.20,46.40,48.32,50.06,66.96,116.72$, 123.84, 127.52, 141.50, 141.52, 145.32, 148.68, 219.70 ppm. EI-MS m/z: 368.17. Anal. Calcd. for $\mathrm{C}_{21} \mathrm{H}_{24} \mathrm{~N}_{2} \mathrm{O}_{4}$ : C, 68.46; H, 6.57; N, 7.60; O, 17.37. Found: C, 68.44; H, 6.53.

Synthesis of 2-[(17S)-17-methyl-16-oxo-5-oxapentacyclo [10.7. 0.02,9.04,7.013,17]nonadeca-2,4(7),8-trien-6-yl]acetonitrile (3).

In a round bottom flask $(10 \mathrm{ml})$, compound $2(200 \mathrm{mg}, 0.54 \mathrm{mmol})$, potassium carbonate (60 mg, $0.43 \mathrm{mmol}$ ), and $5 \mathrm{ml}$ of dimethyl sulfoxide were stirred at reflux for $12 \mathrm{~h}$. Then, the solvent was evaporated under reduced pressure and following the product was 
purified via crystallization using the methanol:water (4:1) system; yielding 54\% of product; m.p. $112-114{ }^{\circ} \mathrm{C}$; IR $\left(V_{\max }, \mathrm{cm}^{-1}\right) 2240,1712$ and $1312:{ }^{1} \mathrm{H}$ NMR $\left(300 \mathrm{MHz}, \mathrm{CDCl}_{3}-d\right) \delta \mathrm{H}: 0.90$ (s, 3H), 1.20-1.92 (m, 7H), 2,00-2.80 (m, 8H), 3.12-3.30 (m, 2H), $6.56(\mathrm{~m}, 1 \mathrm{H}), 6.80-7.08(\mathrm{~m}$, $2 \mathrm{H}) \mathrm{ppm} .{ }^{13} \mathrm{C} \mathrm{NMR}\left(300 \mathrm{~Hz}, \mathrm{CDCl}_{3}\right) \delta \mathrm{c}: 13.82,21.70,22.74,25.87,27.52,29.32,31.50,35.44$, 37.56, 46.88, 48.11, 50.40, 74.96, 112,80, 119.16, 124.10, 125.96, 130.90, 137.62, 160.46, 220.70 ppm. EI-MS m/z: 321.17. Anal. Calcd. for $\mathrm{C}_{21} \mathrm{H}_{23} \mathrm{NO}_{2}$ : C, 78.47; H, 7.21; N, 4.36; O, 9.96. Found: C, 78.44; H, 7.18.

\subsection{Synthesis of two oxime-steroids derivatives.}

In a round bottom flask $(10 \mathrm{ml})$, compound $3(200 \mathrm{mg}, 0.62 \mathrm{mmol})$, hydroxylamine $(100 \mu \mathrm{l}, 3.66 \mathrm{mmol})$, and $5 \mathrm{~mL}$ of dimethyl sulfoxide were stirred at room temperature for 72 hours. Then, the solvent was evaporated under reduced pressure, and following the crude oil, the product was purified with column chromatography using the ethyl acetate:hexane:methanol system (1:1:3) to give the compounds $\mathbf{4}$ (dark yellow solid) and $\mathbf{5}$ (brown solid).

2-[(16E,17S)-16-hydroxyimino-17-methyl-5-oxapentacyclo[10. $\quad 7.0 .02,9.04,7.013,17] n$ nnadeca-2,4(7),8-trien-6-yl]acetonitrile (4)

Yielding 54\% of product; m.p. 126-128 ${ }^{\circ} \mathrm{C}$; IR $\left(V_{\max }, \mathrm{cm}^{-1}\right) 3332,2240$ and $1312:{ }^{1} \mathrm{H}$ NMR $\left(300 \mathrm{MHz}, \mathrm{CDCl}_{3}-d\right) \delta_{\mathrm{H}}: 1.00(\mathrm{~s}, 3 \mathrm{H}), 1.22-1.92(\mathrm{~m}, 7 \mathrm{H}), 2.06-2.84(\mathrm{~m}, 8 \mathrm{H}), 3.12-3.32$ $(\mathrm{m}, 2 \mathrm{H}), 6.56(\mathrm{~m}, 1 \mathrm{H}), 6.94-7.10(\mathrm{~m}, 1 \mathrm{H}), 8.86$ (broad, $1 \mathrm{H}) \mathrm{ppm} .{ }^{13} \mathrm{C} \mathrm{NMR}\left(300 \mathrm{~Hz}, \mathrm{CDCl}_{3}\right)$ $\delta \mathrm{C}: 16.24,21.40,22.74,26.00,27.02,29.30,29.42,31.82,32.40,37.62,44.54,45.44,53.02$, 74.96, 113.88, 119.18, 124.06, 127.22, 130.92, 139.03, 160.44, $172.60 \mathrm{ppm}$. EI-MS m/z: 336.18. Anal. Calcd. for $\mathrm{C}_{21} \mathrm{H}_{24} \mathrm{~N}_{2} \mathrm{O}_{2}$ : C, 74.97; H, 7.19; N, 8.33; O, 9.51. Found: C, 74.94; H, 7.16.

2-[(16Z,17S)-16-hydroxyimino-17-methyl-5-oxapentacyclo $\quad[10.7 .0 .02,9.04,7.013,17] n o-$ na-deca-2,4(7),8-trien-6-yl]aceto-nitrile (5)

Yielding 54\% of product; m.p. 156-158 ${ }^{\circ} \mathrm{C}$; IR $\left(V_{\max }, \mathrm{cm}^{-1}\right) 3332,2240$ and 1312: ${ }^{1} \mathrm{H}$ NMR (300 MHz, $\left.\mathrm{CDCl}_{3}-d\right) \delta_{\mathrm{H}}: 1.00(\mathrm{~s}, 3 \mathrm{H}), 1.22-1.92(\mathrm{~m}, 7 \mathrm{H}), 2.06-2.84(\mathrm{~m}, 8 \mathrm{H}), 3.12-3.32$ $(\mathrm{m}, 2 \mathrm{H}), 6.56(\mathrm{~m}, 1 \mathrm{H}), 6.94-7.10(\mathrm{~m}, 2 \mathrm{H}), 8.94$ (broad, $1 \mathrm{H}) \mathrm{ppm} .{ }^{13} \mathrm{C} \mathrm{NMR}\left(300 \mathrm{~Hz}, \mathrm{CDCl}_{3}\right)$ $\delta_{\mathrm{C}}: 16.24,21.40,22.74,26.00,27.02,29.30,31.82,32.40,37.62,42.44,44.54,53.02,74.96$, 113.88, 119.18, 124.06, 127.22, 130.92, 139.03, 160.44, 172.70 ppm. EI-MS m/z: 338.18. Anal. Calcd. for $\mathrm{C}_{21} \mathrm{H}_{24} \mathrm{~N}_{2} \mathrm{O}_{2}$ : C, 74.97; H, 7.19; N, 8.33; O, 9.51. Found: C, 74.94; H, 7.16.

\subsection{Preparation of a Lactam-steroid derivative.}

2-[(18S)-18-methyl-17-oxo-5-oxa-16-azapentacyclo[10.8.0.02, 9.04,7.013,18]icosa-2,4(7), 8-trien-6-yl]acetonitrile (6)

In a round bottom flask $(10 \mathrm{ml})$, compound $4(200 \mathrm{mg}, 0.54 \mathrm{mmol})$ and $5 \mathrm{ml}$ of thionyl chloride were stirred at $-4{ }^{\circ} \mathrm{C}$ for $1 \mathrm{~h}$. Then, a solution of potassium hydroxide $(4 \mathrm{~N}, 10 \mathrm{ml}$; previously heated to $90{ }^{\circ} \mathrm{C}$ ) was added. The reaction mixture was stirred for $12 \mathrm{~h}$ at room temperature. The crude product was extracted with chloroform and this solvent was evaporated under reduced pressure and following the product was purified via crystallization using the methanol:hexane:water (3:1:1) system; yielding 54\% of the product; m.p. $182-184^{\circ} \mathrm{C}$; IR $\left(V_{\max }\right.$, $\left.\mathrm{cm}^{-1}\right)$ 2240, 1632 and 1312: ${ }^{1} \mathrm{H}$ NMR $\left(300 \mathrm{MHz}, \mathrm{CDCl}_{3}-d\right) \delta_{\mathrm{H}}: 0.96(\mathrm{~s}, 3 \mathrm{H}), 1.22-1.60(\mathrm{~m}, 3 \mathrm{H})$, $1.66(\mathrm{~m}, 1 \mathrm{H}), 1.76(\mathrm{~m}, 1 \mathrm{H}), 1.92(\mathrm{~m}, 1 \mathrm{H}), 2.06-2.80(\mathrm{~m}, 7 \mathrm{H}), 3.12(\mathrm{~m}, 1 \mathrm{H}), 3.30(\mathrm{~m}, 1 \mathrm{H}), 3.32$ $(\mathrm{m}, 1 \mathrm{H}), 3.36(\mathrm{~m}, 1 \mathrm{H}), 6.56(\mathrm{~m}, 1 \mathrm{H}), 6.60-7.10(\mathrm{~m}, 2 \mathrm{H}), 7.28(\mathrm{~m}, 1 \mathrm{H}) \mathrm{ppm} .22 .74,25.12,25.44$, 28.60, 28.78, 29.30, 35.22, 37.64, 39.29, 42.62, 44.09, 49.50, 74.96, 112.76, 119.16, 124.10, 
128.12, 130.90, 138.54, 160.46, 182.66 ppm. EI-MS m/z: 338.18. Anal. Calcd. for $\mathrm{C}_{21} \mathrm{H}_{24} \mathrm{~N}_{2} \mathrm{O}_{2}$ : C, 74.97; H, 7.19; N, 8.33; O, 9.51. Found: C, 74.93; H, 7.16.

\subsection{Pharmacophore evaluation.}

The 3D pharmacophore model for the Lactam-steroid derivative was determined using LigandScout 4.08 software $[16,17]$.

2.4. Theoretical evaluation of the interaction Lactam-steroid derivative with coronavirusSARCOV19 (6LU7 protein).

The interaction of Lactam-steroid derivative with 6LU7 protein [18] was carried out using two Docking models, such as Chimerax and Achilles-Blind Docking Server [19, 20].

\section{Results and Discussion}

For several years, some compounds have been developed for the treatment of virus strains using expensive reagents, which require special conditions. Besides, the interaction of these compounds with the virus surface is confusing. In this way, in this study, two new steroid derivatives were prepared to evaluate their interaction with SARS-CoV-2 surface using a docking model as follows:

\subsection{Chemicals synthesis.}

3.1.1. Synthesis of a steroid-acetonitrile derivative.

There are several reports for the synthesis of nitrile derivatives using some protocols which involve different reagents such as oxzolidinones [21], $\mathrm{Ph}(\mathrm{OAc})_{2}$ [22], $\mathrm{Tf}_{2} \mathrm{O} / \mathrm{NEt}_{3}$ [23], $\mathrm{Pt}(\mathrm{II})$ [24], chloroamine-T [25] and others. Analyzing these data in this study compound $\mathbf{2}$ was prepared from a steroid-carbaldehyde derivative, $n$-Butyllitium, and acetonitrile (Figure 1).

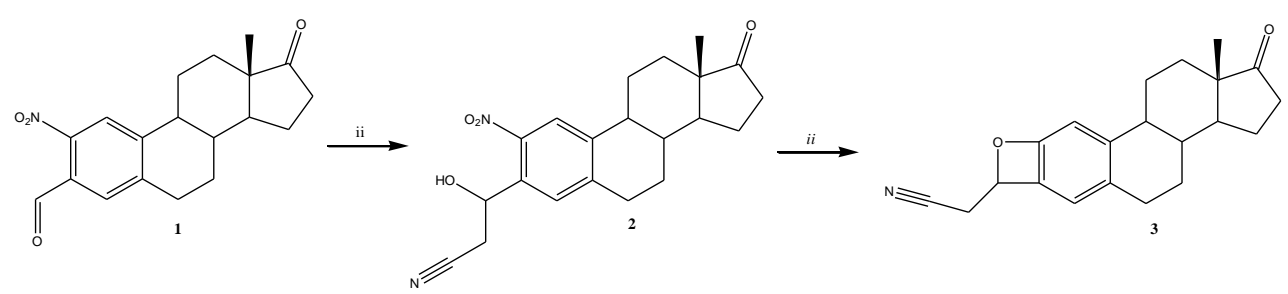

Figure 1. Synthesis of an oxete-steroid derivative (3). Reagents and Conditions: $i=n$-Butyllitium, acetonitrile, room temperature, $72 \mathrm{~h} ; i i=$ potassium carbonate dimethyl sulfoxide, reflux, $12 \mathrm{~h}$.

The mechanism involves the extraction of a proton from acetonitrile by lithium and addition of the anion to carbonyl and then the addition of a proton to oxygen to form a hydroxyl group. (Figure 2).

The ${ }^{1} \mathrm{H}$ NMR spectrum from 2 showed several signals at $0.92 \mathrm{ppm}$ for methyl group; at 1.20-1.52, 1.80-2.80, 3.04 and 7.30-8.04 ppm for steroid moiety; at1.68 ppm for hydroxyl group; at 3.02 and $3.20 \mathrm{ppm}$ for methylene group bound to nitrile group; at $4.86 \mathrm{ppm}$ for methylene group bound to the hydroxyl group. ${ }^{13} \mathrm{C}$ NMR spectra showed chemical shifts at $13.82 \mathrm{ppm}$ for methyl group; at 21.70-25.42, 27.52-50.06 and 123.84-148.68 ppm for steroid moiety; at $27.49 \mathrm{ppm}$ for methylene group bound to nitrile group; at $66.96 \mathrm{ppm}$ for methylene group bound to hydroxyl group; at $116.72 \mathrm{ppm}$ for nitrile group; at $219.70 \mathrm{ppm}$ for ketone group. Besides, the mass spectrum from 2 showed a molecular ion (m/z) 368.17. 


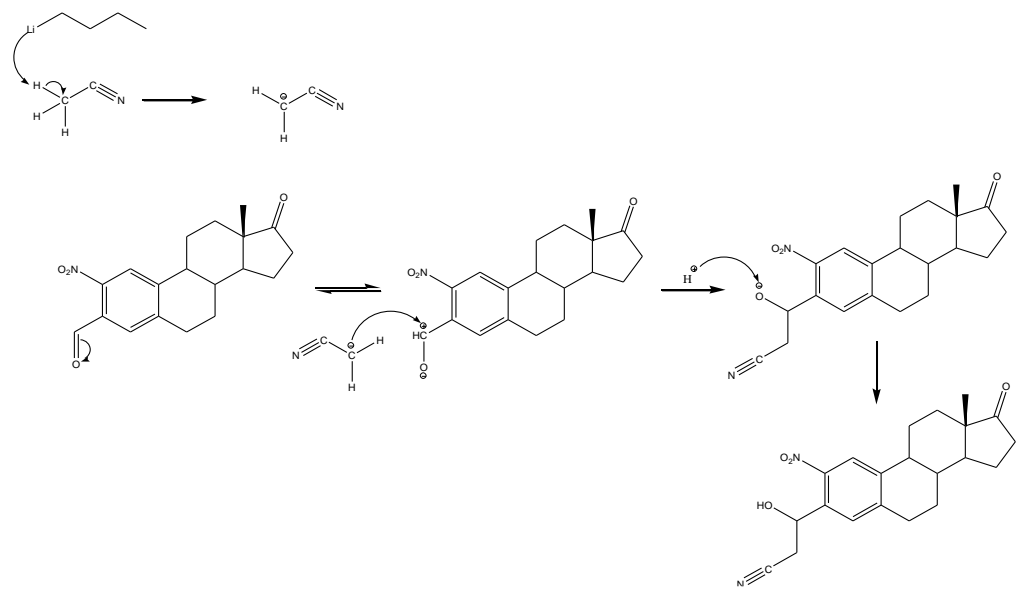

Figure 2. Reaction mechanism involved in the synthesis of a steroid-acetonitrile derivative (2).

\subsubsection{Preparation of an oxete-steroid derivative.}

There are reports on the synthesis of several oxete analogs which use some reagents such as Triphenylphosphine [26] sulfuryl fluoride [27], $\mathrm{MgBr}_{2}$ [28], fluorouracil fluorides [29] and others. Analyzing these data, in this study, an oxete-steroid derivative (3) was prepared via the intramolecular reaction of both hydroxyl and nitro groups involved in the chemical structure of 2 (Figure 1). The ${ }^{1} \mathrm{H}$ NMR spectrum from 3 showed several signals at $0.92 \mathrm{ppm}$ for methyl group; at $0.90 \mathrm{ppm}$ for methyl group; at $1.20-2.80$ and $6.80-7.08 \mathrm{ppm}$ for steroid moiety; at 3.12-3.80 ppm for methylene group bound to both oxete ring and nitrile group; at $6.56 \mathrm{ppm}$ for oxete ring; ${ }^{13} \mathrm{C}$ NMR spectra showed chemical shifts at $13.82 \mathrm{ppm}$ for methyl group; at 21.70 , 25.87-50.40, 112.80 and 124.10-160.46 ppm for steroid moiety; at 22.74 ppm for methylene bound to both oxete ring and nitrile group; at $74.96 \mathrm{ppm}$ for oxete ring; at $119.16 \mathrm{ppm}$ for nitrile group; at $220.70 \mathrm{ppm}$ for ketone group. Finally, the mass spectrum from $\mathbf{3}$ showed a molecular ion $(\mathrm{m} / \mathrm{z}) 321.17$.

\subsubsection{Preparation of two oxime-steroid derivatives.}

Several protocols use some reagents such as $\mathrm{Ru}(\mathrm{III})$ [30], $\mathrm{K}_{3} \mathrm{PO}_{4}$ [31] [bmIm] OH, [32], and $\mathrm{CuSO}_{4}$ [33] and others for preparation of oxime analogs. In this investigation, two oximesteroid derivatives (compounds $\mathbf{4}$ or 5) were prepared from $\mathbf{3}$ and hydroxylamine in the presence of dimethyl sulfoxide (Figure 3). It is noteworthy that separation of the oxime-steroid derivatives was carried out on column chromatography using the ethyl acetate:hexane system; the results showed that yield for $\mathbf{4}$ of $55 \%$ was higher compared to 5 (8\%).

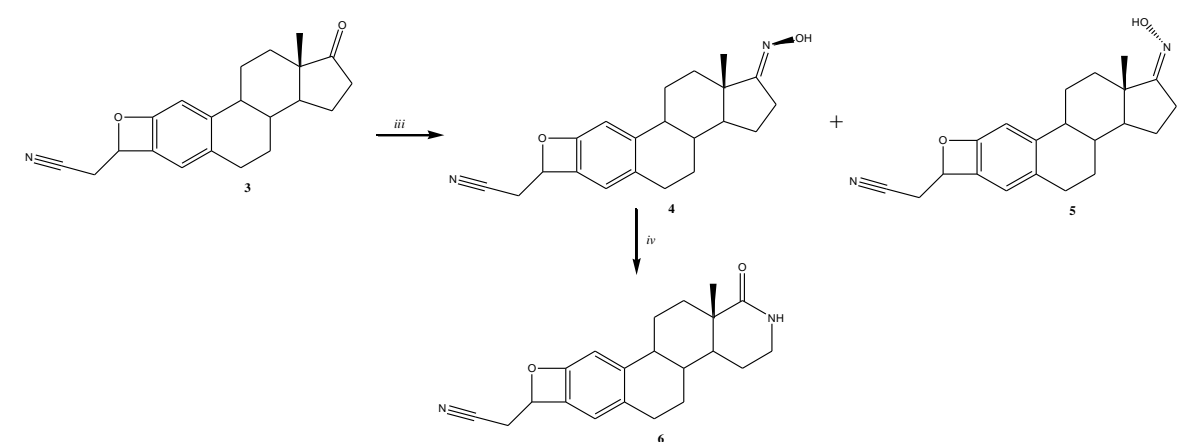

Figure 3. Synthesis of a Lactam-steroid derivative. Reagents and Conditions: $i i i=$ hydroxylamine, dimethyl sulfoxide, room temperature, $72 \mathrm{~h} ; i v=$ thionyl chloride, $-4{ }^{\circ} \mathrm{C}, 1 \mathrm{~h}$, potassium hydroxide room temperature, $12 \mathrm{~h}$. 
The ${ }^{1} \mathrm{H}$ NMR spectrum from 4 showed several signals at 1.00 ppm for methyl group; at 1.22-2.84 and 6.94-7.10 ppm for steroid moiety; at 3.12-3.32 ppm for methylene group bound to both nitrile group and oxete ring; at $6.56 \mathrm{ppm}$ for oxete ring; at $8.86 \mathrm{ppm}$ for a hydroxyl group. ${ }^{13} \mathrm{C}$ NMR spectra display chemical shifts at $16.24 \mathrm{ppm}$ for methyl group; at 21.40-26.00, $53.02,113.88$ and $124.06-160.44 \mathrm{ppm}$ for steroid moiety; at $22.74 \mathrm{ppm}$ for methylene bound to both nitrile group and oxete ring; at $74.96 \mathrm{ppm}$ for oxete ring; at $119.18 \mathrm{ppm}$ for nitrile group; at $172.60 \mathrm{ppm}$ for oxime group. In addition, the mass spectrum from 4 showed a molecular ion $(\mathrm{m} / \mathrm{z}) 338.18$.

On the other hand, The ${ }^{1} \mathrm{H}$ NMR spectrum from 5 showed several signals at $1.00 \mathrm{ppm}$ for methyl group; at 1.22-2.84 and 6.94-7.10 ppm for steroid moiety; at 3.12-3.32 ppm for methylene group bound to both nitrile group and oxete ring; at $6.56 \mathrm{ppm}$ for oxete ring; at 8.94 ppm for a hydroxyl group. ${ }^{13} \mathrm{C}$ NMR spectra display chemical shifts at $16.24 \mathrm{ppm}$ for methyl group; at 21.40-26.00, 53.02, 113.96 and 124.06-160.44 ppm for steroid moiety; at $22.74 \mathrm{ppm}$ for methylene bound to both nitrile group and oxete ring; at $74.96 \mathrm{ppm}$ for oxete ring; at 119.18 ppm for nitrile group; at $172.70 \mathrm{ppm}$ for oxime group. Besides, the mass spectrum from $\mathbf{5}$ showed a molecular ion $(\mathrm{m} / \mathrm{z}) 338.18$.

\subsubsection{Preparation of a Lactam-steroid derivative.}

There are several reports to the synthesis of lactam analogs using some reagents such as carbodiimide derivatives [34] $\mathrm{SnCl}_{4}$ [35], $\mathrm{Ag}_{2} \mathrm{O}$ [36], Benzoylamides [37], and others. In this investigation, compound 6 was prepared from 4 , thionyl chloride in middle conditions. The ${ }^{1} \mathrm{H}$ NMR spectrum from 5 showed several signals at $0.96 \mathrm{ppm}$ for methyl; at 1.22-1.60, 1.76, 2.06-2.80 and 6.60-7.40 ppm for 1,2,3,4,4a,9,10,10a-Octahydro-phenanthrene system; at 1.66, 1.92, 3.30, 3.36 and $7.28 \mathrm{ppm}$ for Piperidin-2-one ring; at 3.12 and $3.32 \mathrm{ppm}$ for methylene bound to both nitrile group and oxete ring; at $6.56 \mathrm{ppm}$ for oxete ring. ${ }^{13} \mathrm{C} \mathrm{NMR}$ spectra display chemical shifts at 22.74 for methylene group bound to both nitrile group and oxete ring; at $25.12 \mathrm{ppm}$ for methyl group; at 25.44-28.60, 29.30-39.29, 44.09-49.50, 118.76, 124.10-160.46 ppm for 1,2,3,4,4a,9, 10,10a-Octahydro-phenanthrene system; at 28.78 and $42.62 \mathrm{ppm}$ for Piperidin-2-one ring; at $74.96 \mathrm{ppm}$ for oxete ring; at $119.16 \mathrm{ppm}$ for nitrile group; at $182.66 \mathrm{ppm}$ for ketone group. Finally, the mass spectrum from $\mathbf{6}$ showed a molecular ion $(\mathrm{m} / \mathrm{z}) 338.18$.

\subsubsection{Pharmacophore ligand model.}

Several chemical models have been used to determine the three-dimensional orientation adopted by the functional groups of a molecule to predict its interaction with several biomolecules [26]; for example, the use of a pharmacophore model which can furnish a new insight to design novel molecules that can enhance or inhibit the function of a biological target which can be useful in new drug discovery. Analyzing this premise in this study, the LigandScout software $[10,11]$ was used to develop a pharmacophore model for compound Lactam-steroid derivative (Figures 4 and 5). The results showed that functional groups involved in these compounds could interact via hydrophobic contacts or as hydrogen bond acceptors or as hydrogen bond donor with some biomolecules. 


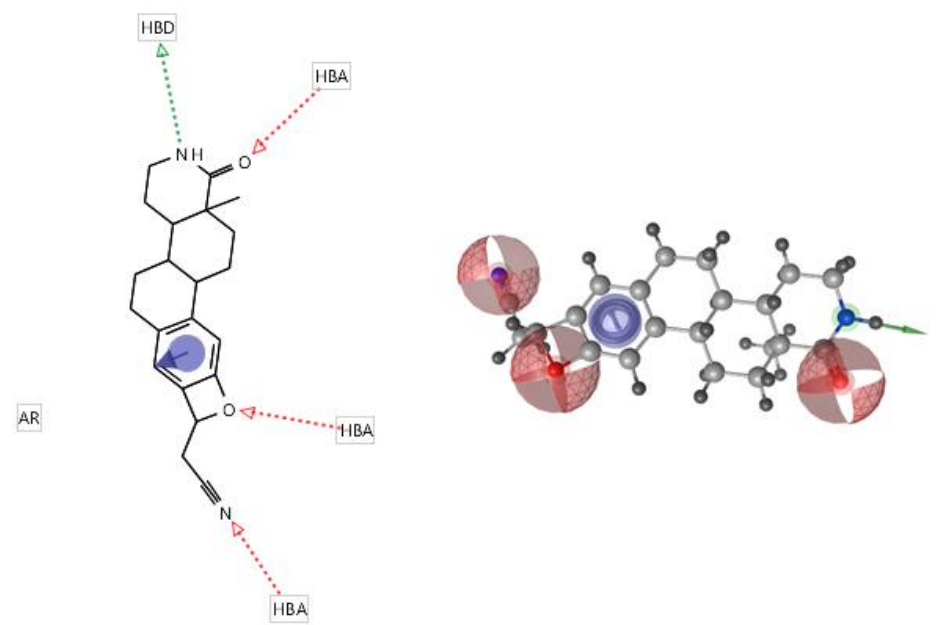

Figure 4. Scheme represents a pharmacophore from Lactam-steroid derivative using the LigandScout software. The model involves a hydrogen bond acceptor (HBA, red) and hydrogen bond donor (HBD, green).

\subsubsection{Interaction theoretical.}

Some studies have used to predict the interaction of several drugs with different biomolecules using some theoretical models [38-40]. This investigation was carried out a theoretical analysis on the interaction of Lactam-steroid derivative with coronavirus (6UL7 protein) using both hydroxychloroquine and favipiravir as controls in two Docking models such as Chimerax and Achilles-Blind Docking Server (Figure 5). The results (Tables 1-6) showed differences in the interaction of either hydroxychloroquine, favipiravir, and Lactamsteroid derivative with 6LU7 protein surface.

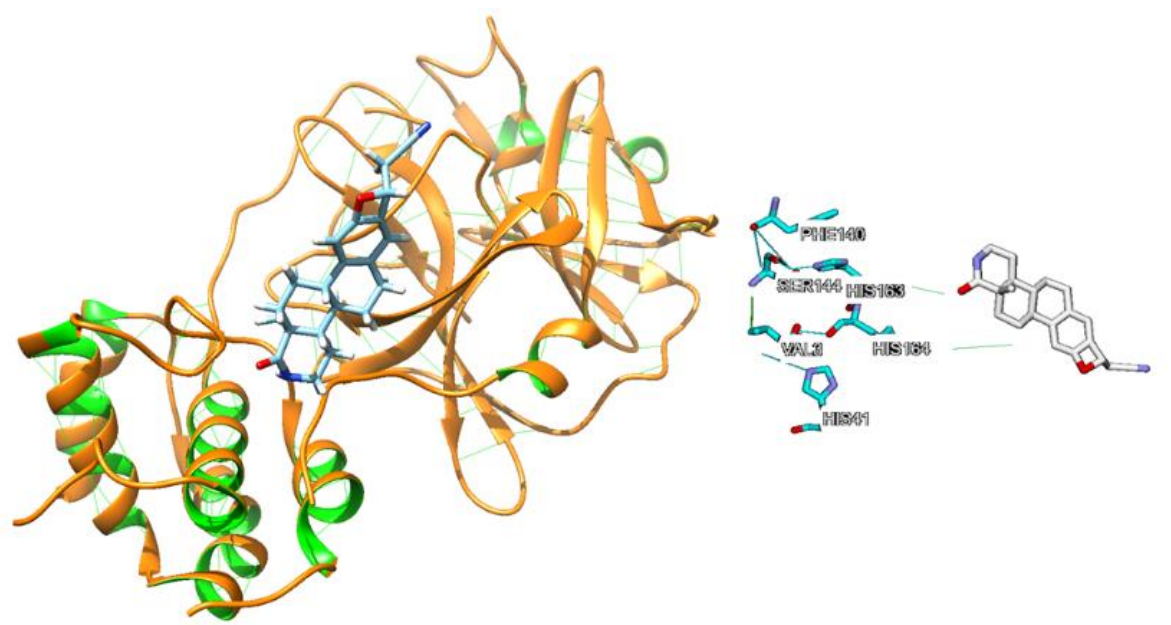

Figure 5. Aminoacid residues involved between the interaction of Lactame-steroid derivative, 6LU7 protein surface.

Table 1. Hydrogen bonds of Lactam-steroid derivative with SAR-COCID2 (6LU7).

\begin{tabular}{l|l|l|l}
$\begin{array}{l}\text { Aminoacid } \\
\text { residue }\end{array}$ & Distance H-A & Distance D-A & Don angle \\
\hline His 137 & 2.30 & 3.16 & 139.61 \\
\hline Glu $_{290}$ & 3.29 & 4.03 & 137.58
\end{tabular}

Table 2. Hydrophobic bonds of Lactam-steroid derivative with SAR-COCID2 (6LU7).

\begin{tabular}{l|l} 
Aminoacid residue & Distance \\
\hline Leu $_{272}$ & 3.77 \\
\hline Leu $_{286}$ & 3.84 \\
\hline Leu 287 & 3.89
\end{tabular}


Table 3. Hydrogen bonds of Favipiravir with SAR-COCID2 (6LU7).

\begin{tabular}{l|l|l|l}
$\begin{array}{l}\text { Aminoacid } \\
\text { residue }\end{array}$ & Distance H-A & Distance D-A & Don angle \\
\hline $\mathrm{Gln}_{110}$ & 1.96 & 2.91 & 153.68 \\
\hline $\mathrm{Thr}_{111}$ & 3.13 & 3.89 & 132.10 \\
\hline $\mathrm{Gln}_{127}$ & 3.45 & 4.02 & 117.00 \\
\hline $\mathrm{Asn}_{151}$ & 3.51 & 3.88 & 103.68 \\
\hline $\mathrm{Thr}_{282}$ & 2.19 & 3.04 & 148.46 \\
\hline $\mathrm{Asp} 295$ & 3.14 & 4.03 & 147.54
\end{tabular}

Table 4. Hydrophobic bonds of Favipiravir derivative with SAR-COCID2 (6LU7).

\begin{tabular}{l|l} 
Aminoacid residue & Distance \\
\hline Phe 294 & 3.49
\end{tabular}

Table 5. Hydrogen bonds of Hydroxychloroquine with SAR-COCID2 (6LU7).

\begin{tabular}{l|l|l|l}
$\begin{array}{l}\text { Aminoacid } \\
\text { residue }\end{array}$ & Distance H-A & Distance D-A & Don angle \\
\hline Asp $_{153}$ & 2.68 & 3.15 & 112.18 \\
\hline Ser 158 & 2.23 & 3.16 & 165.98
\end{tabular}

Table 6. Hydrophobic bonds of Favipiravir derivative with SAR-COCID2 (6LU7).

\begin{tabular}{l|l} 
Aminoacid residue & Distance \\
\hline Phe 8 & 3.91 \\
\hline Val $_{104}$ & 3.55 \\
\hline Gln $_{110}$ & 3.83 \\
\hline Phe 294 & 3.64
\end{tabular}

\subsubsection{Binding energy.}

To evaluate the binding energy involved in the interaction of compounds Lactamsteroid, Hydroxychloroquine, and Favipiravir, the Achilles-Blind Docking Server was used. The results showed low binding energy for Lactam-steroid derivative compared with both compounds Hydroxychloroquine and Favipiravir (Table 7 and Figure 6). this phenomenon could be due to differences in the chemical structure of each compound.

Table 7. Binding energy of compounds Hydroxychloroquine, Favipiravir, and Lactam-steroid derivative involved with the interaction of SAR-COCID2 (6LU7).

\begin{tabular}{l|l} 
Compound & Binding energy \\
\hline Fivipiravir & -5.30 \\
\hline Hydroxychloroquine & -5.70 \\
\hline Lactam-derivative & -7.60
\end{tabular}

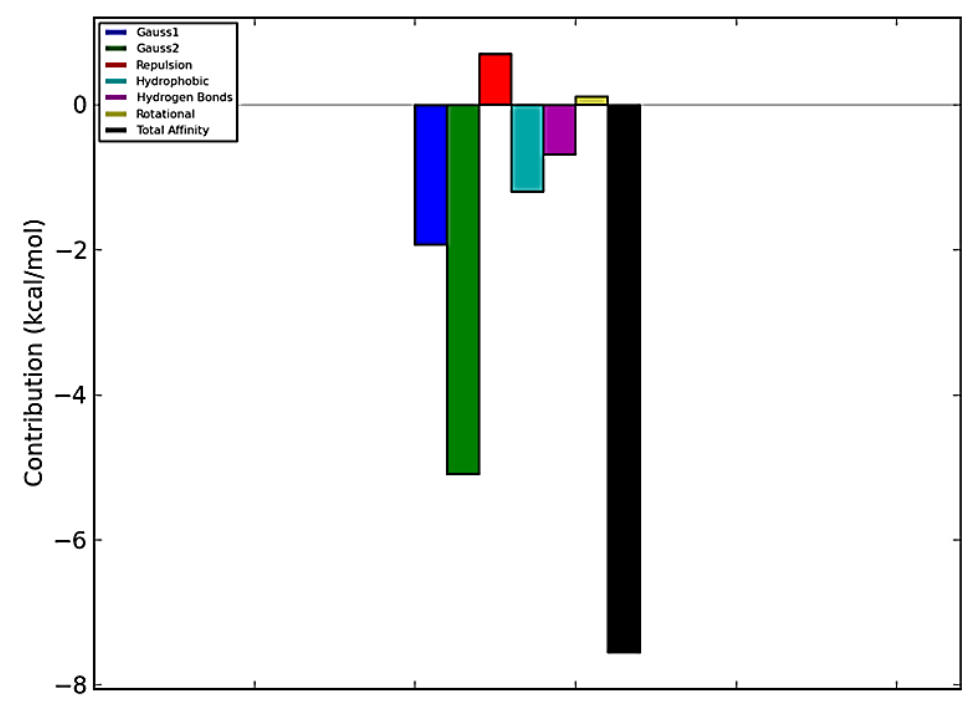

Figure 6. Binding energy involved in the interaction of Lactam-steroid derivative with 6LU7 protein surface using Achilles-Blind Docking Server. 


\section{Conclusions}

In this study, facile synthesis of a Lactam-steroid derivative using some chemical strategies is reported. Besides, Theoretical analysis of the interaction of Lactam-steroid derivative with 6LU7 protein surface showed binding energy lower compared to binding values for both hydroxychloroquine and favipiravir. In conclusion, the lactam-steroid derivative could be an alternative therapeutic to treatment of SARS-CoV.

\section{Funding}

This research received no external funding.

\section{Acknowledgments}

To Benjamin Valverde and Raquel Anzurez, for your unconditional support on this manuscript.

\section{Conflicts of Interest}

The authors declare no conflict of interest.

\section{References}

1. Lu, R.; Zhao, X.; Li, J.; Niu, P.; Yang, B.; Wu, H.; Bi, Y. Genomic characterisation and epidemiology of 2019 novel coronavirus: implications for virus origins and receptor binding. The Lancet 2020, 395, 565-574, https://doi.org/10.1016/S0140-6736(20)30251-8.

2. Baig, A.; Khaleeq, A.; Ali, U.; Syeda, H. Evidence of the COVID-19 virus targeting the CNS: tissue distribution, host-virus interaction, and proposed neurotropic mechanisms. ACS chemical Neuroscience 2020, 11, 995-998, https://doi.org/10.1021/acschemneuro.0c00122.

3. Zelenev, A.; Li, J.; Mazhnaya, A.; Basu, S.; Altice, F. Hepatitis C virus treatment as prevention in an extended network of people who inject drugs in the USA: a modelling study. The Lancet Infectious Diseases 2018, 18, 215-224, https://doi.org/10.1016/S1473-3099(17)30676-X.

4. Sorbo, M.; Cento, V.; Di Maio, V.; Howe, A.; Garcia, F.; Perno, C.; Ceccherini, F. Hepatitis C virus drug resistance associated substitutions and their clinical relevance: Update 2018. Drug Resistance Updates 2018, 37, 17-39, https://doi.org/10.1016/j.drup.2018.01.004.

5. Günthard, H.; Calvez, V.; Paredes, R.; Pillay, D.; Shafer, R.; Wensing, A.; Richman, D. Human immunodeficiency virus drug resistance: 2018 recommendations of the International Antiviral Society-USA panel. Clinical Infectious Diseases 2019, 68, 177-187, https://doi.org/10.1093/cid/ciy463.

6. Sarrazin, C. The importance of resistance to direct antiviral drugs in HCV infection in clinical practice. Journal of hepatology 2016, 64.2, 486-504, https://doi.org/10.1016/j.jhep.2015.09.011.

7. Woolhouse, M.; Jeremy, F. Policy: an intergovernmental panel on antimicrobial resistance. Nature 2014, 509, 555-557, https://doi.org/10.1038/509555a.

8. Cho, J.; Bernard, D.; Sidwell, R.; Kern, E.; Chu, C. Synthesis of cyclopentenyl carbocyclic nucleosides as potential antiviral agents against orthopoxviruses and SARS. Journal of medicinal chemistry 2006, 49, 11401148, https://doi.org/10.1021/jm0509750.

9. Li, Z.; Khaliq, M.; Zhou, Z.; Post, C.; Kuhn, R.; Cushman, M. Design, synthesis, and biological evaluation of antiviral agents targeting flavivirus envelope proteins. Journal of medicinal chemistry 2008, 51, 46604671, https://doi.org/10.1021/jm800412d.

10. Antonín, H.; Ivan, V.; Milena, M.; Graciela, A.; Robert, S.; Lieve, N.; Erik, C.; Jan, B. 6-[2(Phosphonomethoxy) alkoxy] pyrimidines with antiviral activity. Journal of medicinal chemistry 2002, 45, 1918-1929, https://doi.org/10.1021/jm011095y.

11. Santos, G.; Murray, A.; Pujol, C.; Damonte, E.; Maier, M. Synthesis and antiviral activity of sulfated and acetylated derivatives of $2 \beta, \quad 3 \alpha$-dihydroxy-5 $\alpha$-cholestane. Steroids 2003, 68, 125-132, https://doi.org/10.1016/S0039-128X(02)00166-6.

12. Romanutti, C.; Castilla, V.; Coto, C.; Wachsman, M. Antiviral effect of a synthetic brassinosteroid on the replication of vesicular stomatitis virus in Vero cells. International journal of antimicrobial agents 2007, 29, 311-316, https://doi.org/10.1016/j.ijantimicag.2006.11.005.

13. Giner, J.; Faraldos, J. A biomimetic approach to the synthesis of an antiviral marine steroidal orthoester. The Journal of organic chemistry 2002, 67, 2717-2720, https://doi.org/10.1021/jo011111z. 
14. Comin, M.; Maier, M.; Roccatagliata, A.; Pujol, C.; Damonte, E. Evaluation of the antiviral activity of natural sulfated polyhydroxysteroids and their synthetic derivatives and analogs. Steroids 1999, 64, 335-340, https://doi.org/10.1016/s0039-128x(99)00016-1.

15. Lauro, F.; Francisco, D.; Maria, L.; Rolando, G.; Marcela, R.; Virginia, M.; Yazmin, O. Design and synthesis of a bismethylsulfanyl-steroid-azetyl butanol derivative from 2-nitroestradiol. Journal of Heterocyclic Chemistry 2020, 57, 1737-1747, https://doi.org/10.1002/jhet.3899.

16. Saxena, S.; Abdullah, M.; Sriram, D.; Guruprasad, L. Discovery of novel inhibitors of Mycobacterium tuberculosis MurG: Homology modelling, structure-based pharmacophore, molecular docking, and molecular dynamics simulations. Journal of Biomolecular Structure and Dynamics 2018, 36, 3184-3198, https://doi.org/10.1080/07391102.2017.1384398.

17. Kainrad, T.; Hunold, S.; Seidel, T.; Langer, T. LigandScout Remote: A new User-Friendly Interface for HPC and Cloud Resources. Journal of Chemical Information and Modeling 2018, 59, 31-37, https://doi.org/10.1021/acs.jcim.8b00716.

18. Adebambo, K. Computational Investigation of the Interaction of Anti-Influenza Drugs with CoVID-19 Protein. Computational Molecular Bioscience 2020, 10, 45, https://doi.org/10.4236/cmb.2020.102003.

19. Lung, J.; Lin, Y.; Yang, Y.; Chou, Y.; Shu, L.; Cheng, Y.; Wu, C. The potential chemical structure of antiSARS-CoV-2 RNA-dependent RNA polymerase. Journal of Medical Virology 2020, 92, 693-697, https://doi.org/10.1002/jmv.25761.

20. Goddard, T.; Huang, C.; Meng, E.; Pettersen, E.; Couch, G.; Morris, J.; Ferrin, T. UCSF ChimeraX: Meeting modern challenges in visualization and analysis. Protein Science 2018, 27, 14-25, https://doi.org/10.1002/pro.3235.

21. Sibi, M.; Takahiro, S.; Craig, P. Nitrile Ylides: Diastereoselective Cycloadditions using Chiral Oxzolidinones Without Lewis Acid. Organic letters 2009,11,5366-5369, https://doi.org/10.1021/ol9018584.

22. Mendelsohn, A.; Shelley, L.; Simon, K.; Florian, T.; Virender, S.; Marco, A. Oxidation of oximes to nitrile oxides with hypervalent iodine reagents. Organic letters 2009, 11, 1539-1542, https://doi.org/10.1021/o1900194v.

23. Dieter, M.; Jeffrey, W.; Erick, M. A novel, general method for the synthesis of nitrile oxides: dehydration of O-silylated hydroxamic acids. Organic letters 2000, 2, 539-541, https://doi.org/10.1021/o1991396q.

24. Mukherjee, A.; Rai-Shung, Liu. Chemoselectivities in the platinum-catalyzed hydrative carbocyclizations of oxo-alkyne-nitrile functionalities. Organic letters 2011, 13, 660-663, https://doi.org/10.1021/ol1029047.

25. Tony, K.; Wai, F.; Hau, M.; Wun, S.; King, H. Intramolecular nitrile oxide-alkene cycloaddition of sugar derivatives with unmasked hydroxyl group (s). Organic letters 2007, 9, 753-756, https://doi.org/10.1021/ol062873p.

26. Asghari, S.; Ahmad, K. Triphenylphosphine-catalyzed synthesis of stable, functionalized $2 \mathrm{H}$-oxetes. Phosphorus, Sulfur, and Silicon 2005, 180, 2451-2456, https://doi.org/10.1080/104265090921182.

27. Revathi, L.; Ravindar, L.; Balakrishna, M.; Rakesh, K.; Hua-Li, Q. SO2F2-mediated transformation of 2'hydroxyacetophenones to benzo-oxetes. Beilstein journal of organic chemistry 2019, 15, 976-980, https://doi.org/10.3762/bjoc.15.95.

28. Magali, O.; Jean-Marc, P.; Jean-Luc, P.; Michel, R. Experimental evidence for a [2+ 2] mechanism in the Lewis acid-promoted formation of $\alpha, \beta$-unsaturated esters from ethoxyacetylene and aldehydes. Synthesis and characterisation of 4-ethoxyoxetes. Chemical Communications 1998, 16, 1619-1620, https://doi.org/10.1039/A803395A.

29. Barlow, M.; Coles, B.; Haszeldine, R. Heterocyclic polyfluoro-compounds. Part 34 [1]. Two-way photochemical addition of hexafluoroacetone to 1,2-dichlorofluoroethylene, and the preparation of an oxete. Journal of Fluorine Chemistry 1980, 15, 381-386, https://doi.org/10.1016/S0022-1139(00)81771-6.

30. Da-Ho, L.; Otog, N.; Fujisawa, I.; Iwasa, S. Catalytic Asymmetric Carbene Transfer Reactions of Diazo Oxime Ethers with Olefins and Their Synthetic Applications. Organic letters 2019, 21, 7470-7474, https://doi.org/10.1021/acs.orglett.9b02771.

31. Quibria, G.; Proulx, C. Oxime Ligation via in situ Oxidation of N-Phenylglycinyl Peptides. Organic letters 2018, 20, 2564-2567, https://doi.org/10.1021/acs.orglett.8b00713.

32. Zang, H.; Wang, M.; Cheng, B.; Song, J. Ultrasound-promoted synthesis of oximes catalyzed by a basic ionic liquid $[\mathrm{bmIm}] \quad \mathrm{OH} . \quad$ Ultrasonics sonochemistry. 2009, 16, 301-303, https://doi.org/10.1016/j.ultsonch.2008.09.003.

33. Sharghi, H.; Sarvari, M. Selective Synthesis of E and Z Isomers of Oximes. Synlett 2001, 2001, 0099-0101, https://doi.org/10.1055/s-2001-9719.

34. Mosca, S.; Yu, Y.; Gavette, J.; Zhang, K.; Rebek, J. A deep cavitand templates lactam formation in water. Journal of the American Chemical Society 2015, 137, 14582-14585, https://doi.org/10.1021/jacs.5b10028.

35. Ejima, H.; Wakita, F.; Imamura, R.; Kato, T.; Hosokawa, S. Stereoselective Synthesis of Tabtoxinine- $\beta$ lactam by Using the Vinylogous Mukaiyama Aldol Reaction with Acetate-Type Vinylketene Silyl N, OAcetal and $\alpha$-Keto- $\beta$-lactam. Organic letters 2017, 19, 2530-2532, https://doi.org/10.1021/acs.orglett.7b00814. 
36. Campa, R.; Manzano, R.; Calleja, P.; Ellis, S.; Dixon, D. Enantioselective Silver-Catalyzed Cascade Synthesis of Fused Lactone and Lactam Oxazolines. Organic letters 2018, 20, 6033-6036, https://doi.org/10.1021/acs.orglett.8b02383.

37. Huh, S.; Hong, S.; Chang, S. Synthetic Utility of N-Benzoyloxyamides as an Alternative Precursor of Acylnitrenoids for $\gamma$-Lactam Formation. Organic Letters 2019, 21, 2808-2812, https://doi.org/10.1021/acs.orglett.9b00791.

38. Das, S.; Sarmah, S.; Lyndem, S.; Singha R. An investigation into the identification of potential inhibitors of SARS-CoV-2 main protease using molecular docking study. Journal of Biomolecular Structure and Dynamics 2020, 1-18, https://doi.org/10.1080/07391102.2020.1763201.

39. El-Mansy, M.; Osman, O.; Mahmoud, A.; Elhaes, H.; Ibrahim, M. Computational notes on the molecular modeling analyses of flutamide. Letters in Applied NanoBioScience 2020, 9, 1099-1102, https://doi.org/10.33263/LIANBS92.10991102.

40. Muhammad, A.; Arfan, N.; Wa, H.; Laode, K. In silico exploration for aldose reductase (AR) inhibitors. Letters in Applied NanoBioScience 2020, 9, 956-960, https://doi.org/10.33263/LIANBS92.956960. 